\title{
Molecular diversity of symbiotic algae at the latitudinal margins of their distribution: dinoflagellates of the genus Symbiodinium in corals and sea anemones
}

\author{
A. M. Savage ${ }^{1}$, M. S. Goodson ${ }^{1}$, S. Visram ${ }^{1}$, H. Trapido-Rosenthal ${ }^{2}$, J. Wiedenmann ${ }^{3}$, \\ A. E. Douglas ${ }^{1, *}$ \\ ${ }^{1}$ Department of Biology, University of York, PO Box 373, York YO10 5YW, United Kingdom \\ ${ }^{2}$ Bermuda Biological Station for Research, Ferry Reach, Bermuda GE01 \\ ${ }^{3}$ Department of General Zoology and Endocrinology, University of Ulm, Albert Einstein Allee 11, 89069 Ulm, Germany
}

\begin{abstract}
To investigate the molecular diversity of symbiotic algae at the latitudinal limits of their distribution, the ribosomal RNA gene sequences (rDNA) of the dinoflagellate Symbiodinium in benthic Cnidaria (corals, sea anemones etc.) on Bermuda $\left(32^{\circ} \mathrm{N}\right)$ and in the Mediterranean and $\mathrm{NE}$ Atlantic $\left(35\right.$ to $\left.53^{\circ} \mathrm{N}\right)$ were analysed. The algae in Bermudian Cnidaria were identified as Symbiodinium of Phylotypes A, B and C, as previously described for benthic Cnidaria in the Caribbean $\left(12\right.$ to $\left.27^{\circ} \mathrm{N}\right)$. The algae in every sample of sea anemones (Anemonia spp. and Cereus pedunculatus) in the NE Atlantic and Mediterranean were a previously undescribed group within Phylotype A, possibly endemic to this high latitude region.
\end{abstract}

KEY WORDS: Symbiosis $\cdot$ Symbiodinium $\cdot$ Zooxanthellae $\cdot$ Molecular diversity $\cdot$ Marginal populations

\section{INTRODUCTION}

Reef-building scleractinian corals and most other benthic Cnidaria (e.g. sea anemones, gorgonians) on shallow water coral reefs bear dinoflagellate algae of the genus Symbiodinium in their tissues. These symbiotic algae provide the animal with nutrients, thereby promoting animal growth and reproduction as well as enhancing calcification in scleractinian corals (Trench 1993, Gattuso et al. 1999). Coral reefs are restricted to low latitudes, generally $25^{\circ} \mathrm{N}$ to $25^{\circ} \mathrm{S}$, where mean winter sea surface temperatures do not fall below $18^{\circ} \mathrm{C}$ (Stehli \& Wells 1971). At higher latitudes, with greater seasonal variation in temperature and day length, coral reefs and Cnidaria bearing Symbiodinium are of low species diversity or absent (Crossland 1988, Veron 1995). Symbiodinium have rarely

${ }^{*}$ Corresponding author. Email: aed2@york.ac.uk been reported in the free-living condition and those that have are invariably close to symbioses (Carlos et al. 1999), suggesting that free-living populations are small and transient (i.e. individual cells of Symbiodinium derived from symbioses may not persist indefinitely in the natural environment).

The purpose of this study was to investigate the molecular diversity of Symbiodinium at the latitudinal limits of symbioses in Cnidaria. We predicted that Symbiodinium diversity would be low and include divergent, possibly endemic, forms as a result of isolation or adaptation to the high latitude environment. Our study area was the Atlantic and the sites were Bermuda at $32^{\circ} \mathrm{N}$ in the West Atlantic, the European coast of the Mediterranean at 35 to $43^{\circ} \mathrm{N}$, and coastal waters of the UK, France and Italy at 48 to $53^{\circ} \mathrm{N}$. Bermuda is the most northerly reef site in the Atlantic Ocean, warmed by eddies of the Gulf Stream (Verrill 1901). Benthic Cnidaria bearing Symbiodinium on Bermuda are generally accepted as conspecific with 
members of the Caribbean fauna, but they are of much reduced diversity, e.g. of the 62 species of scleractinian corals bearing symbiotic algae on Jamaica, 17 have been reported on Bermuda (Logan 1988). The benthic cnidarian fauna of coastal waters of the NE Atlantic is different from low latitudes and dominated by taxa lacking Symbiodinium. Exceptionally, sea anemones of the genus Anemonia are widespread and locally abundant, for example to $57^{\circ} \mathrm{N}$ along the west coast of Britain (Pax \& Müller 1962, A. E. Douglas unpubl. obs.: for consideration of taxonomy of Anemonia species, see Wiedenmann et al. 1999, 2000). The diversity of Symbiodinium in Anemonia species from UK waters and the Mediterranean was determined. For comparison, an analysis was conducted of Symbiodinium in a second sea anemone genus, Cereus pedunculatus, which is locally common in coastal waters throughout the NE Atlantic coastal waters (Manuel 1988).

The chosen approach to investigate the molecular diversity of Symbiodinium is sequence variation in ribosomal RNA genes. Sequence analysis of the smallsubunit (SSU) rDNA has revealed 2 broad groups, one containing Phylotype A and the other containing Phylotypes B, C and E (Rowan \& Powers 1991a, Rowan \& Knowlton 1995). Phylotype $\mathrm{E}$ is known as Phylotype D by some authors (e.g. LaJeunesse 2001). The various phylotypes can be discriminated by PCR-RFLP analysis of SSU rDNA (e.g. Rowan \& Powers 1991b, Rowan \& Knowlton 1995, Darius et al. 1998, Brown et al. 2002). Phylogenetic trees constructed from partial sequences of the large-subunit (LSU) rRNA gene and complete sequences of the ITS/5.8 S regions are congruent with those obtained with SSU rRNA gene (Wilcox 1998, LaJeunesse 2001, Pawlowski et al. 2001).

Of immediate relevance to this study, sequence data have been used to examine the geographical distribution of Symbiodinium phylotypes. Most scleractinian corals in the Caribbean bear Phylotypes A, B and C (varying between species) and corals in the Pacific generally have Phylotype C (Baker \& Rowan 1997). Phylotype E has been reported in several coral species in both the Caribbean and Pacific (e.g. Rowan \& Knowlton 1995, Van Oppen et al. 2001, Toller et al. 2001a, Brown et al. 2002). Phylotypes A, B, C and E of Symbiodinium occur in other benthic Cnidaria (e.g. sea anemones, zoanthids, gorgonians) in both the Atlantic and Indo-Pacific (e.g. Rowan \& Powers 1991b, Coffroth et al. 2001). The few studies of Symbiodinium at the latitudinal margins of their distribution include the demonstration that high latitude populations of both Anthopleura elegantissima, a sea anemone on the Pacific coast of North America, and Plesiastrea versipora, a Pacific coral of very wide latitudinal range, have Phylotype B (LaJeunesse \& Trench 2000, Rodri-
guez-Lanetty et al. 2001) and in the UK, the sea anemone Anemonia viridis (= A. sulcata) has Phylotype A (Bythell et al. 1997).

\section{MATERIALS AND METHODS}

The samples and DNA extraction methods. The focus of this study was symbioses from Bermuda and Europe which are listed in Table 1. The Mediterranean/UK samples of Anemonia species and the Bermudian species were collected directly from the natural habitat; Cereus pedunculatus from Brittany (France) was provided fixed in ethanol by W. Westheide (University of Osnabruck). Tropical species were also used: DNA samples of the coral Montastraea annularis at San Blas, Panama, provided by R. Rowan; skeleton-free coral blastates in DMSO/NaCl buffer of Agaricia fragilis, Favia fragum, Siderastrea siderea and Stephanocoenia intersepta at St. Croix, the Virgin Islands, provided by J. Bythell; and frozen cores of the coral Goniastrea aspera from Phuket, Thailand, provided by B. E. Brown.

DNA extraction followed the method of Rowan \& Powers (1991b) or Wiedenmann et al. (2000). For live samples of the sea anemones and the benthic jellyfish Cassiopeia xamachana, fresh tentacle clippings were macerated in ice-cold Zooxanthellae isolation buffer (ZIB) (0.4 M NaCl, $10 \mathrm{mM} \mathrm{Na}$ EDTA, $20 \mathrm{mM}$ Tris, $8 \mathrm{mM}$ dithiothreitol, $\mathrm{pH}$ 8.2); the fixed Cereus pedunculatus was soaked in ZIB and minced finely with scissors before maceration; and for the live and frozen coral samples, tissue was removed from the skeleton using an airbrush and ice-cold ZIB. These treatments yielded intact zooxanthellae and disrupted animal tissues, which were separated by centrifugation and resuspension in fresh ice-cold ZIB 3 times. All the ZIB-prepared material and the samples of fixed coral blastate from St. Croix were washed in DNAB (0.4 M $\mathrm{NaCl}, 50 \mathrm{mM} \mathrm{Na}{ }_{2}$ EDTA, pH 8) and incubated overnight at $50^{\circ} \mathrm{C}$ with $0.5 \mathrm{mg}$ Proteinase $\mathrm{K} \mathrm{ml}^{-1}$ DNAB. The digests were incubated with $1.5 \%$ cetyltrimethylammonium bromide, $1 \mathrm{M} \mathrm{NaCl}$ and $1.5 \mu \mathrm{g}$ glycogen $\mathrm{ml}^{-1}$ (final concentrations). DNA was extracted in chloroform and precipitated in ice-cold ethanol with $0.3 \mathrm{M}$ sodium acetate, $\mathrm{pH} 6.5$.

PCR amplification of zooxanthellae rDNA. Three regions of the dinoflagellate rRNA gene complex were amplified: SSU rDNA with primers ss5z and ss3z (Rowan \& Powers 1991b); 5'-region of LSU rDNA with primers 24D15F1 and 24D2R1 (Baker et al. 1997); and the complete ITS1-5.8S-ITS2 region using primers msg2 (5'- GTA GGT GAA CCT GCG GAA GGA -3') and msg3 (5'- TCC TCC GCT TAC TTA TAT GCT TAA -3'), designed from conserved sequences at 
3'-end of SSU and 5'-end of LSU sequences, respectively, of Symbiodinium rRNA genes available in GenBank. The reaction mixtures contained $2 \mathrm{mM}$ dNTPs, $0.2 \mu \mathrm{M}$ primers, $1 \times$ Taq polymerase buffer (Promega) and $0.05 \mathrm{U} \mathrm{Taq}$ polymerase $\mathrm{\mu l}^{-1}$, with $\mathrm{MgCl}_{2}$ at $1.5 \mathrm{mM}$ for SSU and ITS amplifications and $3.0 \mathrm{mM}$ for LSU amplification. All PCR reactions were carried out in a
PTC-100 ${ }^{\mathrm{TM}}$ thermal cycler (MJ Research) with the thermal profiles: 28 cycles of $45 \mathrm{~s}$ at $94^{\circ} \mathrm{C}, 45 \mathrm{~s}$ at $56^{\circ} \mathrm{C}$ and $2 \mathrm{~min}$ at $72^{\circ} \mathrm{C}$ for SSU amplifications; 30 cycles of $1 \mathrm{~min}$ at $94^{\circ} \mathrm{C}, 1 \mathrm{~min}$ at $54^{\circ} \mathrm{C}$ and $2 \mathrm{~min}$ at $72^{\circ} \mathrm{C}$ for LSU amplifications; and $2 \mathrm{~min}$ at $94^{\circ} \mathrm{C}$, followed by 35 cycles of $1 \mathrm{~min}$ at $56^{\circ} \mathrm{C}, 2 \mathrm{~min}$ at $72^{\circ} \mathrm{C}, 1 \mathrm{~min}$ at $94^{\circ} \mathrm{C}$ and then $1 \mathrm{~min}$ at $56^{\circ} \mathrm{C}, 8 \mathrm{~min}$ at $72^{\circ} \mathrm{C}$ for ITS amplifications.

Table 1. Symbioses: collection site and phylotype of Symbiodinium as determined by PCR-RFLP analysis of SSU rDNA

\begin{tabular}{|c|c|c|c|c|}
\hline $\begin{array}{l}\text { (a) Europe } \\
\text { Host species }\end{array}$ & Collection site ${ }^{a}$ & & $\mathrm{~N}^{\mathrm{b}}$ & Phylotype \\
\hline \multirow[t]{2}{*}{ Anemonia rustica } & Giglio, Italy & & 2 & A \\
\hline & Colliure, France & & 1 & A \\
\hline \multirow{2}{*}{ Anemonia sulcata var. rufescens } & Colliure, France & & 4 & A \\
\hline & Gallinzana Bay, Ell & & 1 & A \\
\hline \multirow[t]{4}{*}{ Anemonia sulcata var. smaragdina } & Giglio, Italy & & 1 & A \\
\hline & Colliure, France & & 4 & A \\
\hline & Gallinzana Bay, Ell & & 1 & A \\
\hline & Aquarium 'Wilheln & Germany $^{c}$ & 1 & A \\
\hline Anemonia sulcata var. viridis & Colliure, France & & 3 & A \\
\hline \multirow[t]{2}{*}{ Anemonia sulcata var. viridis } & Cornwall, UK & & 50 & A \\
\hline & Lleyn Peninsula, U & & 10 & A \\
\hline Anemonia sulcata var. vulgaris & Giglio, Italy & & 2 & A \\
\hline Cereus pedunculatus & Brittany, France & & 4 & A \\
\hline \multicolumn{5}{|l|}{ (b) Bermuda } \\
\hline \multirow{2}{*}{ Host species } & \multirow{2}{*}{$\begin{array}{l}\text { Collection depth }{ }^{\mathrm{a}} \\
\qquad(\mathrm{m})\end{array}$} & \multirow{2}{*}{$\mathrm{N}^{\mathrm{b}}$} & \multicolumn{2}{|c|}{ Phylotype } \\
\hline & & & Bermuda & Caribbean \\
\hline \multicolumn{5}{|l|}{ Scleractinian corals } \\
\hline Agaricia sp. & $3-6$ & 18 & $\mathrm{C}$ & \\
\hline Dichocoenia stokesi & 30 & 1 & B & \\
\hline Diploria labyrinthiformis & $3-30$ & 10 & B & $\mathrm{B}, \mathrm{C}^{\mathrm{d}}$ \\
\hline Diploria strigosa & 5 & 4 & B & $\mathrm{B}^{\mathrm{d}}$ \\
\hline Favia fragum & $3-30$ & 8 & $7 \mathrm{~B}, 1 \mathrm{~A}^{\mathrm{j}}$ & $B^{d}$ \\
\hline Isophyllia sinuosa & $3-6$ & 2 & B & \\
\hline Madracis decactis & $3-30$ & 3 & B & $\mathrm{B}^{\mathrm{d}}$ \\
\hline Madracis mirabilis & 3 & 4 & B & $\mathrm{B}^{\mathrm{d}}$ \\
\hline Meandrina meandrites & 6 & 1 & B & $B^{d}$ \\
\hline Montastraea cavernosa & $2.5-4$ & 16 & $\mathrm{C}$ & $\mathrm{C}^{\mathrm{d}}$ \\
\hline Montastraea franksi ${ }^{\mathrm{k}}$ & $3-30$ & 46 & $44 \mathrm{~B}, 2 \mathrm{~A}$ & $\mathrm{~A}, \mathrm{~B}, \mathrm{C}, \mathrm{E}^{\mathrm{e}}$ \\
\hline Oculina diffusa & $4-28$ & 11 & B & $\mathrm{B}^{\mathrm{f}}$ \\
\hline Porites astreoides & $3-30$ & 11 & A & $\mathrm{A}, \mathrm{C}^{\mathrm{d}}$ \\
\hline Porites porites & $2-6$ & 11 & A & $C^{\mathrm{d}}$ \\
\hline Scolymia sp. & 30 & 2 & $\mathrm{C}$ & \\
\hline Siderastrea radians & $0.5-2$ & 12 & B & $\mathrm{C}^{\mathrm{g}}$ \\
\hline Stephanocoenia intersepta & $5-30$ & 5 & $3 \mathrm{~B}, 2 \mathrm{C}$ & $\mathrm{A}, \mathrm{C}^{\mathrm{d}}$ \\
\hline \multicolumn{5}{|l|}{ Actiniaria } \\
\hline Aiptasia pallida & $0.2-1$ & 32 & B & $\mathrm{B}^{\mathrm{h}}$ \\
\hline Bartholomea annulata & $1-2$ & 25 & A & $\mathrm{A}^{\mathrm{g}}$ \\
\hline Condylactis gigantea & $3-6$ & 17 & $8 \mathrm{~A}, 7 \mathrm{~B}, 2 \mathrm{~A}+\mathrm{B}$ & $\mathrm{A}, \mathrm{C}^{\mathrm{i}}$ \\
\hline Lebrunia danae & 3 & 8 & $\mathrm{C}$ & $\mathrm{B}^{\mathrm{g}}$ \\
\hline \multicolumn{5}{|l|}{ Scyphozoa } \\
\hline Cassiopeia xamachana & $1-3$ & 12 & A & $\mathrm{A}^{\mathrm{h}}$ \\
\hline
\end{tabular}


Supplementary amplifications of SSU rDNA fragments using the universal primers ss5 and ss3 (Rowan \& Powers 1991b) were conducted as described in Bythell et al. (1997). The results were consistent with the amplification products obtained using the SSU primers ss $5 \mathrm{z}$ and $s s 3 z$, confirming that none of the samples contained dinoflagellate algae that cannot be amplified with the latter primers.

Restriction analysis of PCR products. The algal phylotypes were identified by restriction analysis of SSU rDNA fragments with TaqI and DpnII, following the procedure of Bythell et al. (1997). Digestions were run on a $1 \%$ agarose gel in TAE, with a $1 \mathrm{~kb}$ molecular weight ladder (Gibco-BRL) and visualised with ethidium bromide staining under UV illumination. The phylotypes were identified from approximate band sizes: Phylotype A-TaqI 700 and 600 bp, DpnII 850 and $580 \mathrm{bp}$; Phylotype B-TaqI 850 and $500 \mathrm{bp}$, DpnII 750 and 500 bp; Phylotype C-TaqI 880 and 700 bp, DpnII-860 and 500 bp; and Phylotype E-TaqI 720 bp, DpnII 860 and 500 bp (Rowan \& Powers 1991b, Brown et al. 2002). To discriminate among algae of Phylotype A, the PCR-amplified LSU fragments were digested with DdeI following manufacturer's instructions and digestions were run on a $2 \%$ agarose gel, as above.

Sequencing and sequence analysis. The PCR-generated LSU fragment from 1 or 2 samples of each host species was sequenced, and sequence analysis of the ITS1/5.8S/ITS2 region was conducted on 5 individuals of Bermudian Cassiopeia xamachana, Lebrunia danae, Montastraea franksi and Favia fragum, 5 samples of Montastraea annularis from Panama and 10 individuals of Bermudian Aiptasia pallida. The PCR products were routinely cloned prior to sequencing because the resolution of direct sequencing would have been confounded by within-sample sequence variability arising from multiple gene sequences per genome or multiple algal genotypes per symbiosis (see Toller et al. 2001a). With a few exceptions (described in 'Results'), however, the sequence variation between clones of 1 PCR amplification was very low. Each PCR product was purified with QIAquick PCR purification kit (Qiagen) following manufacturer's instructions and ligated into pGEM-T Easy vector (Promega). Calcium-competent cells of Escherichia coli DH5 $\alpha$ were transformed with the resultant plasmids. Recombinant colonies were screened for the insert of the predicted length and plasmids were prepared for sequencing using QIAprep spin miniprep kit columns (Qiagen). PCR products were sequenced from the recombinant plasmid using 2 primers (T7 and SP6, Promega), and a bigdye terminator cycle sequencing ready reaction kit (PE Applied Biosystems). Sequencing reactions were run on $4.25 \%$ polyacrylamide gels in an ABI 377 auto- mated sequencer (PE Applied Biosystems). Sequences were analysed using DNAStar Lasergene software and aligned using ClustalX version 1.8 (Thompson et al. 1997). All sequences were confirmed not to be chimeric molecules generated during amplification using the program CHIMERA. For each PCR product, a consensus sequence was generated from the sequences of 3 clones, determined in both directions; between-clone variation was generally less than $1 \%$ and did not exceed $2.5 \%$. Consensus sequences have been deposited in Genbank (Accession numbers AY074938 to AY074987 and AF478694). Bootstrapped neighbor-joining trees based on a Kimura 2-parameter distance matrix were constructed using ClustalX version 1.8 (Thompson et al. 1997) with gapped positions removed. Parallel analyses with gaps included revealed that gapped regions did not generally exert a strong influence on tree topology (Goodson 2000). Maximum likelihood analysis was performed using the PHYLIP program DNAML with global rearrangement (Felsenstein 1989). Bootstrapped data sets were generated using the PHYLIP program SEQBOOT, and CONSENSE was used to generate the consensus tree.

\section{RESULTS}

\section{Restriction analysis of SSU rDNA}

The PCR amplification product obtained with SSU primers was ca. $1.6 \mathrm{~kb}$ for all algal samples from Bermuda and West Europe. When digested with the restriction enzymes TaqI and DpnII, the products conformed to previously described phylotypes of Symbiodinium (Table 1). The algae in sea anemones from European waters were exclusively of Phylotype A. Phylotypes A, B and C were present in the Bermudian material and 4 out of 22 species were polymorphic (i.e. bore more than 1 phylotype of Symbiodinium): the sea anemone Condylactis gigantea bears Phylotypes A and B, the coral Stephanocoenia intersepta Phylotypes $\mathrm{B}$ and $\mathrm{C}$, and the corals Favia fragum and Montastraea franksi Phylotypes A and B. Three corals Diploria labyrinthiformis, Montastraea franksi and Porites astreoides tend to have Phylotype $\mathrm{C}$ in deep waters in the Caribbean (Baker \& Rowan 1997), but Phylotype C was absent from all Bermudian samples of these species at depths to $30 \mathrm{~m}$ (Table 1 ).

Comparison of the diversity of Symbiodinium in Bermudian and Caribbean scleractinian corals is feasible because all Bermudian species are also present in the Caribbean (see 'Introduction'). The Symbiodinium in 13 out of 17 Bermudian scleractinian species have been typed previously in the Caribbean (Table 1). For 6 species, the Symbiodinium phylotype is identical in 
the Bermudian and Caribbean material, and 3 species apparently have a lower algal diversity on Bermuda than in the Caribbean (Phylotype C reported in Diploria labyrinthiformis and Porites astreoides in the Caribbean but not Bermuda, and Phylotypes $\mathrm{C}$ and $\mathrm{E}$ in Montastraea franski in the Caribbean but not Bermuda). Three species hosted different phylotypes in Bermuda and the Caribbean: Siderastrea radians (Phylotype B on Bermuda, Phylotype C in Caribbean), Porites porites (Phylotype A on Bermuda, Phylotype C in Caribbean) and Stephanocoenia intersepta (Phylotype $\mathrm{B}$ or $\mathrm{C}$ on Bermuda, Phylotype $\mathrm{A}$ or $\mathrm{C}$ in Caribbean). A final detected difference is that all Favia fragum samples from the Caribbean (Baker \& Rowan 1997, and 11 samples tested in this study) and 7 out of 8 samples from Bermuda bore Phylotype B, but 1 Bermudian colony tested had a mixed A/B infection dominated by Phylotype A.

As an approach to investigate the incidence of Symbiodinium phylotypes on Bermuda, the frequency of each phylotype recorded in scleractinian corals from Bermuda (this study) and in the Caribbean by Baker \& Rowan (1997) was compared. With polymorphic species included in the analysis (see Table 2), the most frequent Phylotype is B in Bermudian corals but $\mathrm{C}$ in the Caribbean. The frequency of scleractinian species bearing the various phylotypes differs significantly between Bermuda and the Caribbean $\left(\chi^{2}[2 \mathrm{df}]\right)=7.39$, $\mathrm{p}<0.05)$. If the coral species bearing multiple Symbiodinium phylotypes are excluded from the analysis, the difference is still significant $\left(\chi^{2}[2 \mathrm{df}]=6.24, \mathrm{p}<0.05\right)$.

\section{Sequence analysis of LSU rDNA}

All PCR reactions with LSU primers generated products of ca. $650 \mathrm{bp}$ length, the predicted length for Symbiodinium (Baker et al. 1997). Some reactions with scleractinian coral DNA as template yielded an additional product of ca. $850 \mathrm{bp}$, the predicted length for the animal gene. Sequences of the cloned products of the shorter of the 2 bands were confirmed as Symbiodinium in origin by BLAST searches (Altschul et al. 1990). Most of the PCR products assigned to Symbiodinium were $646 \mathrm{bp}$, comprising the D1 hypervariable domain (145 bp), D2 hypervariable domain (235 bp) and intervening conserved region (159 bp), flanked by $80 \mathrm{bp} \mathrm{5'}$ and $27 \mathrm{bp} \mathrm{3'}$ conserved regions. Deletions (up to $53 \mathrm{bp}$ ) or insertions (up to $19 \mathrm{bp}$ ) were scored in the hypervariable regions of 5 sequences (1 from Oculina diffusa, 2 from Favia fragum and 2 from Montastraea cavernosa); these sequences were not used to construct the consensus sequence for phylogenetic analysis and, in relation to this study, they were not examined further.
Overall, $83 \%$ of the variable sites were in the hypervariable D1 and D2 domains (if the variable sites were evenly distributed throughout the sequence, $63 \%$ of the variable sites would be expected to fall in the D1 and D2 domains); of the variable sites in the hypervariable region, most were in the D2 domain. These results are consistent with patterns of variation reported for non-symbiotic dinoflagellates (Zardoya et al. 1995). Sequence variation within Phylotypes B and C was 0 to $1.9 \%$. Phylotype A, with total sequence variation of 0.1 to $8.7 \%$, comprised 2 groups, each with $<1.9 \%$ variation. One group contained sequences from Anemonia species and Cereus pedunculatus, and the other group comprised sequences from Bermudian species.

The phylogenetic analysis was conducted on the 646 bp fragment of LSU rRNA gene of Symbiodinium in the European and Bermudian material, together with 20 sequences from the Caribbean and Pacific (including sequences from GenBank and previously unpublished data for material from St. Croix, the Virgin Islands and Phuket, Thailand). The neighbor joining tree with the non-symbiotic dinoflagellate Alexandrium catenatum as outgroup is shown in Fig. 1a. The maximum likelihood tree had identical topology, and the tree topologies were unaltered by use of the nonsymbiotic dinoflagellates Gymnodinium simplex (Accession No. AF060991) as outgroup (data not shown). These results are consistent with published data (e.g. Wilcox 1998, Pawlowski et al. 2001) and the phylotype designations from PCR-RFLP analysis of SSU rDNA (Table 1)

Inspection of the LSU trees revealed no evidence for structuring of Phylotype B or C with respect to either geography or host species, i.e. Phylotypes B and C in the Bermudian material did not differ consistently from Caribbean material. In contrast, Phylotype A comprised 2 subgroups with $100 \%$ bootstrap support. One subgroup, which we term 'Standard A', includes all the Phylotype A sequences from Bermuda, the Caribbean and Pacific; and the second subgroup, 'Temperate A', comprises all the sequences from the Mediterranean and NE Europe. There is also bootstrap support for structuring of the 'Standard A' sequences of Symbiodinium into 3 groups: Caribbean and tropical Pacific

Table 2. Frequency of phylotypes of Symbiodinium in scleractinian coral species from Bermuda and the Caribbean

\begin{tabular}{|c|c|c|}
\hline \multirow{2}{*}{$\begin{array}{l}\text { Symbiodinium } \\
\text { phylotype }\end{array}$} & \multicolumn{2}{|c|}{ Number of coral species } \\
\hline & Bermuda $^{\mathrm{a}}$ & Caribbean $^{\mathrm{b}}$ \\
\hline A & 2 & 7 \\
\hline B & 12 & 10 \\
\hline $\mathrm{C}$ & 4 & 19 \\
\hline \multicolumn{3}{|c|}{ aData from this study: bData from Baker \& Rowan (1997 } \\
\hline
\end{tabular}


samples, plus the sea anemone Bartholomea annulata on Bermuda; Bermudian samples (apart from B. annulata), plus the cultured alga Symbiodinium (=Gymnodinium) linucheae isolated from a pelagic jellyfish Linucheae unguiculata in Bermuda, and the Symbiodinium in the benthic jellyfish Cassiopeia xamachana in the Caribbean and Bermuda. We recognise that wider sampling of 'Standard $\mathrm{A}^{\text {' }}$ material is needed to confirm the validity of these subgroups.

Inspection of the partial LSU sequences revealed that 'Standard $\mathrm{A}^{\prime}$ and 'Temperate $\mathrm{A}^{\prime}$ sequences could be discriminated from the products of digestion with the restriction enzyme DdeI, with predicted band sizes of 265, 179, 160 and $46 \mathrm{bp}$ for 'Standard A' and 360, 160, 84 and $64 \mathrm{bp}$ for 'Temperate A'. Restriction analysis confirmed that Symbiodinium from the UK samples of Anemonia sulcata var. viridis $(\mathrm{n}=5)$ and Mediterranean samples of $A$. rustica $(\mathrm{n}=3), A$. sulcata var. smaragina ( $\mathrm{n}=7)$, A. sulcata var. viridis $(\mathrm{n}=3)$, A. sulcata var. rufescens $(\mathrm{n}=5)$ and A. sulcata var. vulgaris $(\mathrm{n}=2)$ had the restriction pattern expected of 'Temperate A'.

\section{ITS1-5.8S-ITS2 region of rDNA}

The principal purpose of the sequence analysis of the full ITS region (i.e. ITS1-5.8S-ITS2) of rDNA was to establish whether the symbiotic algae in Bermudian and Caribbean Cnidaria are distinct, exploiting the greater phylogenetic resolution afforded by the rapidly evolving ITS regions than the SSU and LSU rDNA (Hillis \& Dixon 1991).

Every sample tested yielded a PCR product of ca. $660 \mathrm{bp}$ length. The sequences of the full ITS region from Symbiodinium of Phylotype A were so divergent from Phylotypes B and C that they could not be aligned accurately, and separate phylogenetic trees were constructed (Fig. 1b,c). Identical groupings were obtained for maximum likelihood trees (not shown). All sequences were assigned to the phylotype predicted from SSURFLP analysis apart from 1 sample from Favia fragum which yielded sequences of Phylotypes A and B (see footnote 10 of Table 1).

The full ITS sequences of Symbiodinium from Bermudian Cassiopeia xamachana were identical to each other and to the published sequence for Symbiodinium from C. xamachana in Florida, described by LaJeunesse (2001) as Group A1. The sequence of Phylotype A from Favia fragum grouped with Symbiodinium (=Gymnodinium) linuchae in Group A4 of LaJeunesse (2001) (Fig. 1b). Symbiodinium in Lebrunia danae could be assigned to Phylotype $\mathrm{C}$, but any more specific identification was precluded because the subgroups of Phylotype C lacked strong bootstrap support (Fig. 1c). Most of the (a)

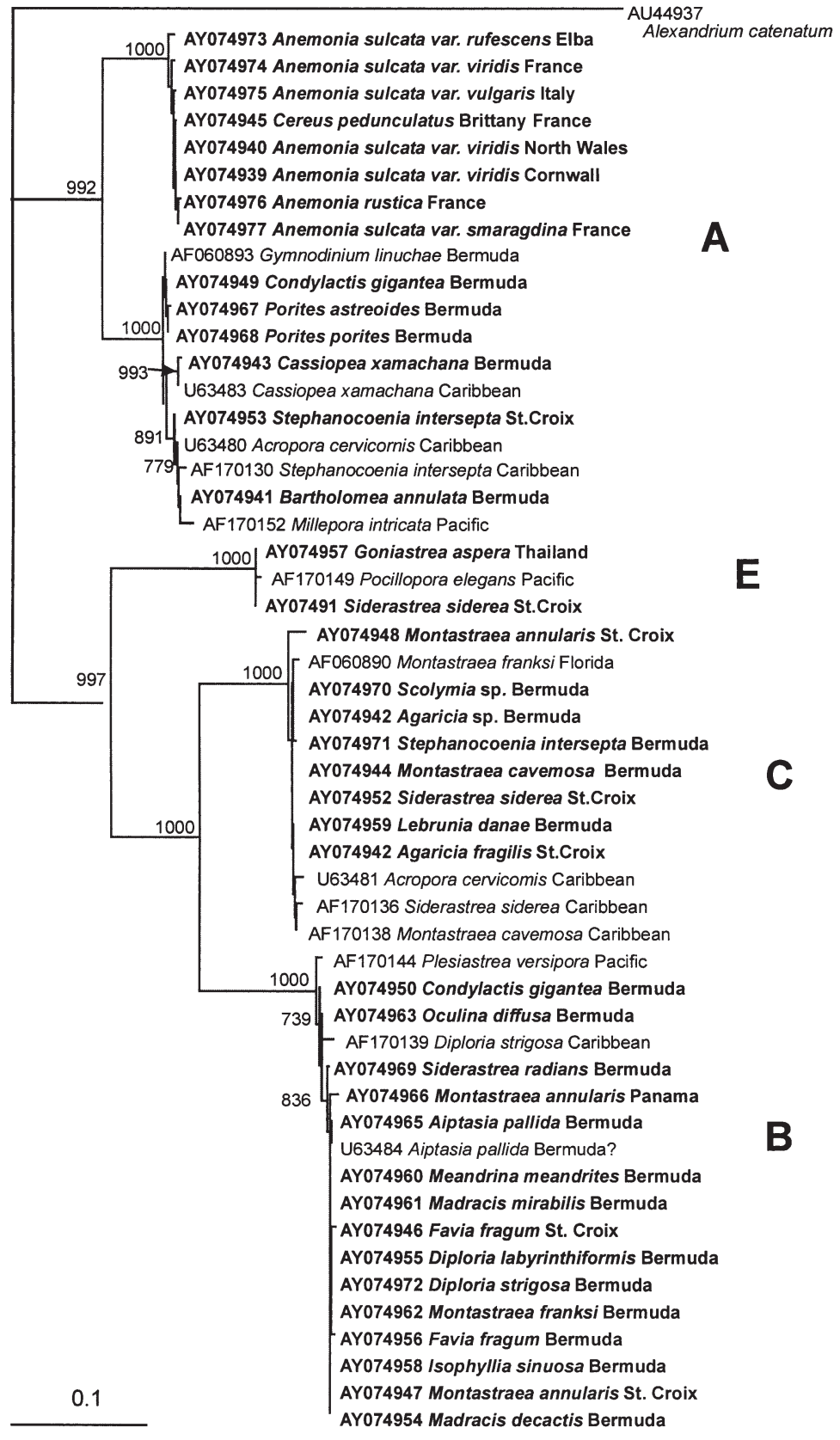

Fig. 1. Neighbor joining trees derived from Symbiodinium rDNA LSU and ITS sequences. (a) Partial LSU-rDNA sequences. (b) ITS1-5.8SITS2 region of rDNA for Phylotype A. (c) ITS1-5.8S-ITS2 region of rDNA for Phylotypes B and C. Bootstrap values (of 1000 replicates) $>70 \%$ are shown at nodes. Branch labels show GenBank accession number, animal species and collection location. Sequences obtained in this study shown in bold 
sequences of Phylotype B on Bermuda, including all the sequences from Montastraea annularis and $F$. fragum and 9 out of 10 sequences from Aiptasia pallida, could be assigned to a single subgroup of Phylotype B that also contained Group B1 of LaJeunesse (2001) obtained from various Caribbean species, including $A$. pallida (Fig. 1c). One of the 5 sequences from Oculina diffusa was also assigned to this group. The 5 samples of Phylotype B from $M$. annularis in Panama analysed here associated with the B1 grouping, but with weak bootstrap support (55\%) (Fig. 1c). The remaining Bermudian sequences, 1 sample from A. pallida (shown as '\#1' in Fig. 1c) and 4 samples from $O$. diffusa, bore very high similarity to sequences from the same species in the Caribbean and could be assigned to Groups B2 and B2.1 of LaJeunesse (2001), respectively.

These data support the conclusion obtained from sequence analysis of LSU rDNA (see above) that the algae in Bermudian Cnidaria are not generally distinct from Symbiodinium in the Caribbean.

\section{DISCUSSION}

The key result of this study is that the molecular diversity of Symbiodinium, the symbiotic algae in corals and allied animals, differs between the high latitude coral reef site of Bermuda $\left(32^{\circ} \mathrm{N}\right)$ and the Mediterranean and NE Atlantic ( 35 to $53^{\circ} \mathrm{N}$ ). The $S y m-$ biodinium on Bermuda and the Caribbean comprises Phylotypes A, B and C; but the Mediterranean and NE Atlantic material bears a previously undescribed group within Phylotype A that we provisionally term 'Temperate $A^{\prime}$. The Bermudian data demonstrate that the reduction in species diversity of cnidarian hosts with increasing latitude (Veron 1995, Karlson \& Cornell 1998) is not necessarily matched by an equivalent reduction in the molecular diversity of Symbiodinium. Additionally, the analysis of Symbiodinium in Anemonia spp. and Cereus pedunculatus has revealed that Phylotype A includes greater molecular diversity than was apparent from analyses based exclusively on tropical material (Rowan 1998). Our results also raise 2 (b)

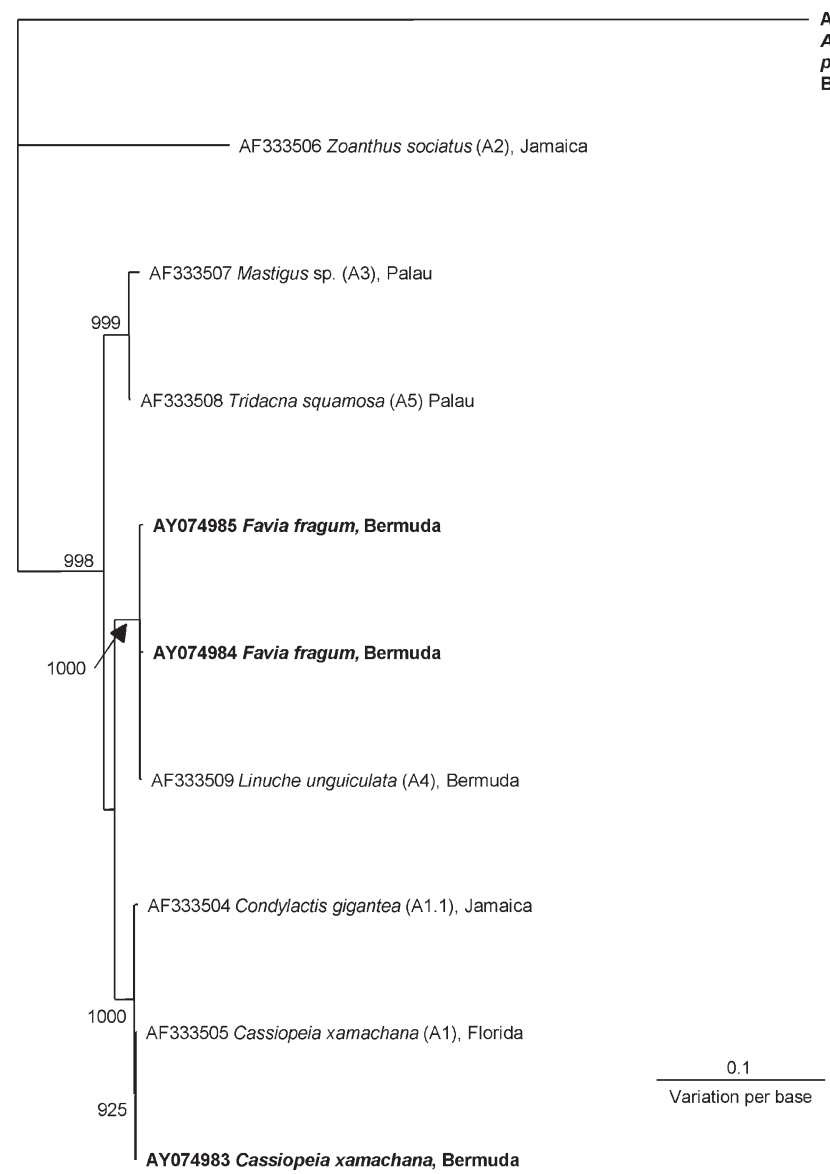

(c)

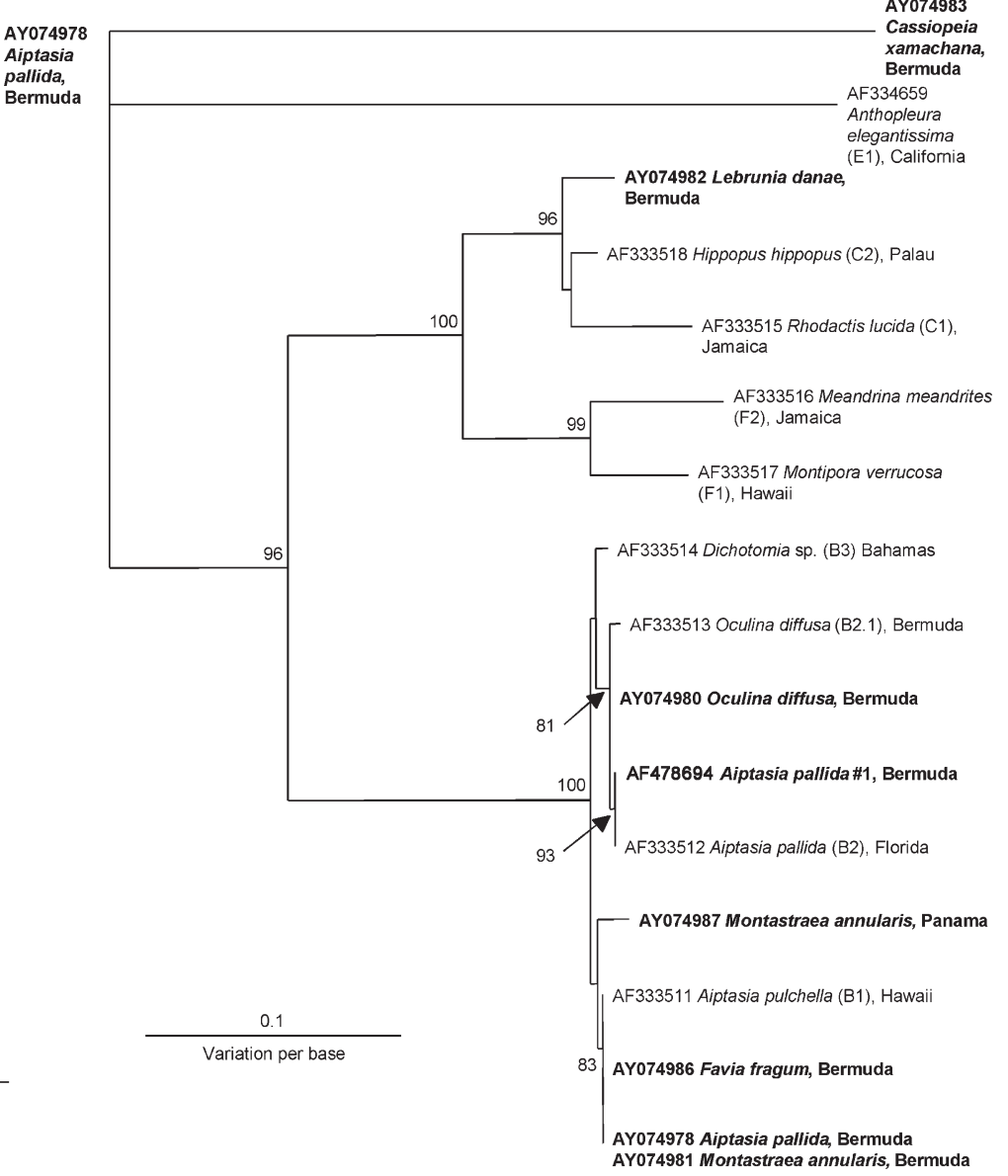

Fig. 1. (continued) 
general issues considered here: (1) the factors shaping the diversity of Symbiodinium at high latitude sites; and (2) the implications of the observed diversity for the ecology of the symbiosis.

\section{Molecular diversity of Symbiodinium at high latitude sites}

The key factors expected to shape the molecular diversity and degree of evolutionary differentiation of Symbiodinium at a marginal site are the connectivity with other sites (as determined by distance, land barriers and prevailing ocean currents) and the environmental conditions (e.g. temperature, irradiance) at the marginal site (Palumbi 1994, Veron 1995, Roberts 1997, Cowan et al. 2000, Bellwood \& Hughes 2001). The high rDNA sequence similarity between Symbiodinium on Bermuda and low latitude sites, including the Caribbean, (Fig. 1) is consistent with the view that the Bermudian Symbiodinium populations, like those of their cnidarian partners (e.g. Logan 1988, Veron 1995), are derived from the Caribbean. A likely dispersal route to Bermuda is via the Gulf Stream. Although the frequency of dispersal from the Caribbean to Bermuda is unknown, the journey time of 2 to $3 \mathrm{wk}$ in the Gulf Stream (Glynn 1973, Lessios et al. 1984) is compatible with the lifespan of some planktonic cnidarian propagules (larvae, polyps) that bear Symbiodinium (e.g. Jokiel 1984, Richmond 1987, BenDavid-Zaslow \& Benayahu 1998, Wilson \& Harrison 1998). Isolated Symbiodinium may also disperse to Bermuda, but their persistence in the water column is unknown.

The high incidence of Phylotype B among the Bermudian fauna can be attributed, at least in part, to the infection of individual cnidarian species by Phylotype B on Bermuda but Phylotype $\mathrm{C}$ in the Caribbean. Symbiodinium of Phylotype C may be selected against in the water column or in the symbioses on Bermuda, or individuals of certain animal species bearing Phylotype C may be at a selective disadvantage. It would, however, be simplistic to conclude that Phylotype C is intrinsically less fit than other phylotypes in the Bermudian environment, because Phylotype $\mathrm{C}$ is borne exclusively by several cnidarian species (Table 1), including Montastraea cavernosa, an abundant coral species on Bermuda at all depths to 60 m (Logan 1988).

The 'Temperate A' group of Symbiodinium, the sole Symbiodinium detected in Anemonia species and Cereus pedunculatus from the NE Atlantic and Mediterranean, has not been described previously in any symbiosis, including other high latitude sites (see 'Introduction'). This suggests that 'Temperate A' may be endemic to the NE Atlantic and Mediterranean, although analysis of further marginal sites, especially in Japan (e.g. Yamano et al. 2001), would be informative. 'Temperate $A^{\prime}$ may be specialised to a few taxa, including Anemonia spp. and C. pedunculatus that extend to particularly high latitudes (Manuel 1988), or may be widely distributed, even universally, among symbioses in these regions. Further research is required to establish the relative importance of isolation and selection in shaping the distribution of the 'Temperate A' group of Symbiodinium. Potential sources of Symbiodinium for these high latitude symbioses include sites in the Atlantic Ocean and, since the construction of the Suez Canal, Red Sea coral reefs; recent invasions of various marine taxa from the Red Sea to the Mediterranean have been reported (Blondel \& Aronson 1999).

\section{Implications of Symbiodinium diversity for the ecology of corals and allied animals}

The ecological consequences of the identity of Symbiodinium in a symbiosis should be addressed with the greatest caution. Although distinctive phenotypes have been attributed to different phylotypes of Symbiodinium, e.g. Phylotype A as 'invasive/opportunistic', C as 'specialist', E as 'stress-tolerant' (Rowan 1998, Toller et al. 2001b), there is now excellent evidence for within-phylotype variation in morphology (Wilcox 1998, LaJeunesse 2001) and ecologically-important traits, such as thermal tolerance (Warner et al. 1999) and photosynthetic response to irradiance (IglesiasPrieto \& Trench 1994). This variation may arise from experience-mediated acclimation (Brown et al. 2001, 2002) and genetic variation within phylotypes not evident at the rDNA sequence level. Of particular relevance to the Bermudian symbioses, Savage (2001) identified statistically significant variation in the photosynthetic response to irradiance among isolates within each of the Phylotypes A, B and C from Bermudian symbioses. For the present, therefore, the Symbiodinium phylotype should be considered as a phylogenetic marker and not equated with any specific phenotypic trait.

The substantial variation in ecologically important traits among Symbiodinium raises the possibility that the diversity of Symbiodinium may contribute to the resilience of symbioses in the face of changes in environmental conditions (Bellwood \& Hughes 2001, Knowlton 2001, Nystrom \& Folke 2001). The principal mechanism is the low specificity of many cnidarian species for Symbiodinium, such that the symbiosis can respond to environmental conditions that favour particular Symbiodinium genotypes (Rowan et al. 1997, Baker 2001). Evidence is accumulating that many ani- 
mal species can form associations with a wider range of Symbiodinium than was believed traditionally. This includes: (1) variation in the Symbiodinium phylotypes between individuals of animal species at different locations (Toller et al. 2001a, this study) and of different developmental ages (Coffroth et al. 2001); (2) Phylotype A at low frequency in the corals Favia fragum and Acropora longicyanthus, which are generally associated with Phylotypes B and C, respectively (Van Oppen et al. 2001, this study); and (3) the realisation that the non-infective isolates in the classical laboratory studies on specificity in Symbiodinium symbioses are 'cryptic' forms that, although readily culturable from symbioses, have never been described as the dominant alga in symbiosis (LaJeunesse 2001, Santos et al. 2001).

If, as is widely accepted in the coral literature, ecosystem resilience is related to diversity (Nystrom \& Folke 2001), the species-poor communities of symbiotic Cnidaria at marginal sites of Bermuda and NE Atlantic and Mediterranean are predicted to be vulnerable to environmental change. The molecular data obtained in this study indicate that this vulnerability may be compounded by low diversity of Symbiodinium in NE Atlantic and Mediterranean to a greater extent than on Bermuda.

Acknowledgements. We thank Drs. J. Bythell, R. Rowan and W. Westheide who kindly provided us with Symbiodinium samples. Linda Roy and Suzanne Lavelle provided preliminary data on Symbiodinium in Siderastrea radians and Anemonia species as part of an internship at BBSR and undergraduate project at University of York, respectively. We thank the Natural Environment Research Council for financial support. This is contribution number 1624 from the Bermuda Biological Station for Research.

\section{LITERATURE CITED}

Altschul SF, Gish W, Miller W, Myers, EW, Lipman DJ (1990) Basic local alignment search tool. J Mol Biol 215:403-410

Baker AC (2001) Reef corals bleach to survive change. Nature 411:765-766

Baker AC, Rowan R (1997) Diversity of symbiotic dinoflagellates (zooxanthellae) in scleractinian corals of the Caribbean and Eastern Pacific. In: Lesslos HA, MacIntyre (eds) Proc 8th Int Coral Reef Symp, Vol 2. Smithsonian Tropical Research Institute, Balboa, Panama, p 1301-1306

Baker AC, Rowan R, Knowlton N (1997) Symbiosis ecology of two Caribbean acroporid corals. In: Lesslos HA, MacIntyre (eds) Proc 8th Int Coral Reef Symp, Vol 2. Smithsonian Tropical Research Institute, Balboa, Panama, p 1295-1300

Banaszak AT, LaJeunesse TC, Trench RK (2000) The synthesis of mycosporine-like amino acids (MAAs) by cultured, symbiotic dinoflagellates. J Exp Mar Biol Ecol 249:219-233

Bellwood DR, Hughes TP (2001) Regional-scale assembly rules and biodiversity of coral reefs. Science 292:1532-1534

Ben-David-Zaslow R, Benayahu Y (1998) Competence and longevity in planulae of several species of soft coral. Mar Ecol Prog Ser 163:235-243
Blondel J, Aronson J (1999) Biology and wildlife of the Mediterranean region. Oxford University Press, Oxford

Brown BE, Dunne RP, Goodson MS, Douglas AE (2001) Marine ecology-bleaching patterns in reef corals. Nature 404:142-143

Brown BE, Dunne RP, Goodson MS, Douglas AE (2002) Experience shapes the susceptibility of a reef coral to bleaching. Coral Reefs 21:119-126

Bythell J, Douglas AE, Sharp VA, Searle JB, Brown BE (1997) Algal genotype and photoacclimatory responses of the symbiotic algae Symbiodinium in natural populations of the sea anemone Anemonia viridis. Proc R Soc Lond Ser B 264:1277-1282

Carlos AA, Baillie BK, Kawachi M, Maruyama T (1999) Phylogenetic position of Symbiodinium (Dinophyceae) isolates from tridacnids (Bivalvia), cardiids (Bivalvia), a sponge (Porifera), a soft coral (Anthozoa), and a free living strain. J Phycol 35:1054-1062

Coffroth MA, Santos SR, Goulet TL (2001) Early ontogenetic expression of specificity in a cnidarian-algal symbiosis Mar Ecol Prog Ser 222:85-96

Cowan RK, Lwiza KMM, Sponagule S, Paris CB, Olson DB (2000) Connectivity of marine populations: open or closed? Science 287:857-859

Crossland CJ (1988) Latitudinal comparisons of coral reef structure and function. In: Proc 6th Coral Reef Symp, Townsville, Australia. Vol 1, p 221-226

Darius HT, Dauga C, Grimont PAD, Chumgue E, Martin PMV (1998) Diversity in symbiotic dinoflagellates (Pyrrhophyta) from seven scleractinian coral species: restriction enzyme analysis of small subunit ribosomal RNA genes. J Eukaryot Microbiol 45:619-627

Felsenstein J (1989) PHYLIP-Phylogeny inference package (version 3.2). Cladistics 5:164-166

Gattuso JP, Allemand D, Frankignoulle M (1999) Photosynthesis and calcification at cellular, organismal and community levels in coral reefs: a review on interactions and control by carbonate chemistry. Am Zool 39:160-183

Glynn PW (1973) Aspects of the ecology of coral reefs in the West Atlantic Province. In: Jones OA, Endean R (eds) Biology and geology of coral reefs. Academic Press, New York, p 273-323

Goodson MS (2000) Symbiotic algae: molecular diversity in marginal coral reef habitats. PhD thesis, University of York, York

Hillis DM, Dixon MT (1991) Ribosomal DNA: molecular evolution and phylogenetic inference. Q Rev Biol 66:411-453

Iglesias-Prieto R, Trench RK (1994) Acclimation and adaptation to irradiance in symbiotic dinoflagellates. I. Responses of the photosynthetic unit to changes in photon flux density. Mar Ecol Prog Ser 113:163-175

Jokiel PL (1984) Long distance dispersal of reef corals by rafting. Coral Reefs 3:113-116

Karlson RH, Cornell HV (1998) Scale-dependent variation in local vs. regional effects on coral species richness. Ecol Monogr 68:259-274

Knowlton N (2001) The future of coral reefs. Proc Natl Acad Sci USA 98:5419-5425

LaJeunesse TC (2001) Investigating the biodiversity, ecology, and phylogeny of endosymbiotic dinoflagellates in the genus Symbiodinium using the ITS region: in search of a 'species' level marker. J Phycol 37:866-880

LaJeunesse TC, Trench RK (2000) Biogeography of two species of Symbiodinium (Freudenthal) inhabiting the intertidal sea anemone Anthopleura elegantissima (Brandt). Biol Bull 199:126-134

Lessios HA, Robertson DR, Cubit JD (1984) Spread of 
Diadema mass mortality through the Caribbean. Science 226:335-337

Logan A (1988) Holocene reefs of Bermuda. Sedimenta 11: $1-144$

Manuel RL (1988) British Anthozoa. In: Kermack DM, Barnes RSK (eds) Synopses of the British fauna (new series). EJ Brill, Leiden

Nystrom M, Folke C (2001) Spatial resilience of coral reefs. Ecosystems 4:406-417

Palumbi SR (1994) Genetic divergence, reproductive isolation and marine speciation. Annu Rev Ecol Syst 25: $547-572$

Pawlowski J, Holzmann M, Fahrni JF, Pochon X, Lee JJ (2001) Molecular identification of algal endosymbionts in large miliolid Foraminifera: 2. Dinoflagellates. J Eukaryot Microbiol 48:368-373

Pax F, Müller I (1962) Anemonia sulcata. In: Die Anthozoenfauna der Adria. Institut für Ozeanographie und Fischerei, Split, p 168-173

Perez SF, Cook CB, Brooks WR (2001) The role of symbiotic dinoflagellates in the temperature-induced bleaching response of the subtropical sea anemone Aiptasia pallida. J Exp Mar Biol Ecol 256:1-14

Richmond RH (1987) Energetics, competency, and longdistance dispersal of planula larvae of the coral Pocillopora damicornis. Mar Biol 93:527-533

Roberts CM (1997) Connectivity and management of Caribbean coral reefs. Science 278:1454-1457

Rodriguez-Lanetty M, Loh W, Carter D, Hoegh-Guldberg O (2001) Latitudinal variability in symbiont specificity within the widespread scleractinian coral Plesiastrea versipora. Mar Biol 138:1171-1181

Rowan R (1998) Diversity and ecology of zooxanthellae on coral reefs. J Phycol 34:407-417

Rowan R, Knowlton N (1995) Intraspecific diversity and ecological zonation in coral-algal symbiosis. Proc Natl Acad Sci USA 92:2850-2853

Rowan R, Powers DA (1991a) A molecular genetic classification of zooxanthellae and the evolution of animal-algal symbioses. Science 251:1348-1351

Rowan R, Powers DA (1991b) The molecular genetic identification of symbiotic dinoflagellates (zooxanthellae). Mar Ecol Prog Ser 71:65-73

Rowan R, Knowlton N, Baker AC, Jara J (1997) Landscape ecology of algal symbionts creates variation in episodes of coral bleaching. Nature 388:265-269

Santos SR, Taylor DJ, Coffroth MA (2001) Genetic comparisons of freshly isolated versus cultured symbiotic dinoflagellates: implications for extrapolating to the intact symbiosis. J Phycol 37:900-912

Savage AM (2001) Genetic diversity and photosynthetic characteristics of Zooxanthellae Symbiodinium. PhD thesis, University of York, York

Stehli FG, Wells JW (1971) Diversity and age patterns in hermatypic corals. Syst Zool 20:115-126

Sterrer W (1986) Marine flora and fauna of Bermuda-a sys-

Editorial responsibility: Otto Kinne (Editor),

Oldendorf/Luhe, Germany tematic guide to the identification of marine organisms. Wiley-Liss Inc, New York

Thompson JD, Gibson TJ, Plewniak F, Jeanmougin F, Higgins DG (1997) The ClustalX windows interface: flexible strategies for multiple sequence alignment aided by quality analysis tools. Nucleic Acids Res 24:4876-4882

Toller WW, Rowan R, Knowlton N (2001a) Zooxanthellae of the Montastraea annularis species complex: patterns of distribution of four taxa of Symbiodinium on different reefs and across depths. Biol Bull 201:360-373

Toller WW, Rowan R, Knowlton N (2001b) Repopulation of zooxanthellae in the Caribbean corals Montastraea annularis and $M$. faveolata following experimental and disease-associated bleaching. Biol Bull 201:348-359

Trench RK (1993) Microalgal-invertebrate symbioses: a review. Endocytobiosis Cell Res 9:135-175

Van Oppen MJH, Palstra FPP, Piquet AMT, Miller DJ (2001) Patterns of coral-dinoflagellate associations in Acropora: significance of local availability and physiology of Symbiodinium strains and host-symbiont selectivity. Proc R Soc Lond Ser B 268:1759-1767

Veron JEN (1995) Corals in space and time: the biogeography and evolution of the Scleractinia. Comstock/Cornell, Ithaca

Verrill AE (1901) Comparisons of the Bermudian, West Indian and Brazilian coral faunae. Trans Connecticut Arts Sci 11: 169-206

Warner ME, Fitt WK, Schmidt GW (1999) Damage to photosystem II in symbiotic dinoflagellates: a determinant of coral bleaching. Proc Natl Acad Sci USA 96:8007-8012

Weil E, Knowlton N (1994) A multi-character analysis of the Caribbean coral Montastraea annularis (Ellis and Solander, 1786) and its two sibling species, M. faveolata (Ellis and Solander, 1786) and M. franksi (Gregory, 1895). Bull Mar Sci 55:151-175

Wiedenmann J, Röcker C, Funke W (1999) The morphs of Anemonia aff. sulcata (Cnidaria, Anthozoa) in particular consideration of the ectodermal pigments. Verh Ges Oekol 29:497-503

Wiedenmann J, Kraus P, Funke W, Vogel W (2000) The relationship between different morphs of Anemonia sulcata PENNANT (Anthozoa, Actinaria) evaluated by DNA fingerprinting. Ophelia 52:57-64

Wilcox TP (1998) Large-subunit ribosomal RNA systematics of symbiotic dinoflagellates: morphology does not recapitulate phylogeny. Mol Phylogenet Evol 10:436-448

Wilson JR, Harrison PL (1998) Settlement competency periods of larvae of three species of scleractinian corals. Mar Biol 131:339-345

Yamano H, Hori K, Yamauchi M, Yamagawa O, Ohmura A (2001) Highest-latitude coral reef at Iki Island, Japan. Coral Reefs 20:9-12

Zardoya R, Costas E, Lopez-Rodas V, Garrido-Pertierra A, Bautista JM (1995) Revised dinoflagellate phylogeny inferred from molecular analysis of large-subunit ribosomal RNA gene sequences. J Mol Evol 41:637-645

Submitted: February 12, 2002; Accepted: July 26, 2002

Proofs received from author(s): October 29, 2002 